\title{
OUTCOME OF SURGICAL TREATMENT OF PROXIMAL HUMERAL FRACTURE
}

\author{
OCENA WYNIKÓW LECZENIA OPERACYJNEGO ZŁAMAŃ \\ NASADY BLIŻSZEJ KOŚCI RAMIENNEJ
}

\begin{abstract}
Department of Orthopedics and Traumatology, Jurasz University Hospital, Collegium Medicum in Bydgoszcz Nicolaus Copernicus University in Torun
\end{abstract}

\section{S u m m a r y}

Glenohumeral joint movement dysfunction, often caused by proximal humeral fracture, limits daily activity. Proximal fracture of the humerus is a common injury which constitutes $5.7 \%$ of all fractures in trauma patients. The aim of the study was the retrospective evaluation of results of surgical treatment of proximal humeral fracture in accordance to fracture type and applied treatment.

The study group consisted of 70 patients who had undergone surgery due to proximal humeral fracture. The mean age in the study group was 55.2 years. The patients were classified according to the AO/ASIF system, based on the preoperative $\mathrm{X}$-ray in comparison to the operative $\mathrm{X}$-ray image. The patients were treated with five methods (ORIF LCP-type plate, ORIF - AO-type plate, ORIF - AO screw(s), CRIF - intramedullary nailing, CRIF - „K” wires). The average time of follow-up amounted to 19.4 months. The function of the glenohumeral joint was assessed after surgery applying the Constant-Murley scale.
The analysis of treatment outcomes showed that in patients operated on for proximal humeral fracture type A and $\mathrm{B}$, the percentage of results described as very good and good was comparable and amounted to approximately $50 \%$. In the smallest group of patients with the most complex type $\mathrm{C}$ fractures, a good and very good result was observed only in $14.29 \%$ of the subjects. The analysis did not show statistically significant differences in treatment results ( $p>0.05$ ). Multiple comparisons showed that regardless of the fracture type, patients received a similar score on the Constant-Murley scale.

Osteosynthesis using LCP plates and angular stabile screws does not improve the treatment outcome in any type of the proximal humeral fracture. However, LCP plates and angular stable screws are used as a standard management for the most severe cases of proximal humeral fracture. Because of a many available treatment techniques, qualification for a particular treatment method should be considered individually for every patient.

\section{Streszczenie}

Dysfunkcja stawu ramiennego powodująca ograniczenie wykonywania wielu codziennych czynności może być następstwem złamania końca bliższego kości ramiennej, które jest częstym obrażeniem narządu ruchu, stanowiącym 5,7\% wszystkich złamań obserwowanych u pacjentów urazowych.

Celem pracy była retrospektywna ocena wyników leczenia operacyjnego złamań końca bliższego kości ramiennej w zależności od typu złamania oraz zastosowanej metody leczenia.
Grupę badaną stanowiło 70 pacjentów leczonych operacyjnie z powodu złamania bliższego końca kości ramiennej. Średnia wieku wynosiła 55,2 lat. Grupę badaną podzielono wg klasyfikacji AO/ASIF na podstawie badania RTG wykonanego przed zabiegiem operacyjnym. Chorych leczono operacyjnie pięcioma metodami (ORIF - LCP-type plate, ORIF - AO-type plate, ORIF - AO screw(s), CRIF intramedullary nailing, CRIF - „K” wires). Średni okres obserwacji chorych wynosił 19,4 miesiąca $( \pm 6,8)$. Funkcję stawu ramienno-łopatkowego oceniono pooperacyjnie w skali Constant. 
Przeprowadzona analiza wyników leczenia wykazała, że wśród leczonych operacyjnie złamań typu A i B odsetek wyników bardzo dobrych i dobrych był podobny i wynosił około 50\%. W najmniej licznej grupie najbardziej złożonych złamań typu C wyniósł on zaledwie 14,29\%. Analiza statystyczna nie wykazała jednak istotnych statycznie różnic w wynikach leczenia $p>0,05$. Porównania wielokrotne wykazały, że niezależnie od typu złamania pacjenci uzyskali podobne wyniki funkcjonalne operowanej kończyny ocenione w skali Constant.

Key words: proximal humerus, fracture, surgery, osteosynthesis Słowa kluczowe: kość ramienna, złamanie, chirurgia, osteosynthesis

\section{INTRODUCTION}

Glenohumeral joint movement dysfunction, often caused by proximal humeral fracture, limits daily activity. An epidemiological study conducted by Court-Brown showed that fractures of the proximal humerus constitute $5.7 \%$ of all trauma fractures with a morbidity rate of 0.63 per 1000 inhabitants [1]. Proximal humerus fracture is twice more common in women and is the 3rd most common fracture type in the elderly $[2,3]$. It is predicted that every 20 th women at the age of 65 will suffer from proximal humeral fracture later in life [4]. Previous studies indicate that $80 \%$ of proximal humeral fractures are recognized as type 1 without displacement, according to the Neer classification [5], and can be successfully managed by non-surgical methods [6,7]. However, it should be noted that the later studies conducted by Court-Brown and Roux described a significantly lower percentage of minimally displaced fractures, ranging from $42 \%$ to $49 \%[8,9]$. Literature on the subject of displaced or complex fractures describes no clear indications or qualification criteria for any particular invasive treatment, as a result of uncertain influence on prognosis $[8,10]$. It is also suggested that there is no significant advantage of surgical treatment over the conservative one [11]. The aim of the study was the retrospective evaluation of results of surgical treatment of proximal humeral fracture in accordance to fracture type and applied treatment.

\section{MATERIAL AND METHOD}

The study group included 70 patients with complete clinical and radiological documentation, surgically treated due to proximal humeral fracture in the Department of Orthopedics and Trauma at University Hospital No. 1 in Bydgoszcz. The study included 30 women and 40 men. The mean age was 55.2 years
Osteosynteza z użyciem płyt LCP i śrub kątowo-stabilnych nie poprawia wyników leczenia w żadnym typie złamania końca bliższego kości ramiennej, tym niemniej zastosowanie płyt LCP i śrub kątowo-stabilnych jest obecnie standardem postępowania $\mathrm{w}$ najcięższych przypadkach złamań końca bliższego kości ramiennej. W związku z szerokim spektrum dostępnych metod leczenia, kwalifikacja do wybranej metody operacyjnej powinna być rozważna i dostosowana indywidualnie do pacjenta.
( \pm 13.7$)$. Patients were classified according to the AO/ASIF system, based on the preoperative X-ray compared to the X-ray image taken in the course of surgery and CT (if performed) [12]. No patients with open fractures were considered in the evaluated group. Proximal humeral fracture was an isolated injury, accompanied by no further fractures or other damage aside from the osteoarticular system. Patients underwent elective surgery within 48 hours from injury. The treatment method was chosen according to the fracture type (type A, B or C). Therefore, procedures were performed through various approaches. The open reduction and internal fixation of proximal humerus fracture was usually performed through the deltopectoral groove. For internal fixation of fractured bones the following techniques were used: anatomical LCP plates with angular stable screws, AO plates with cortical screws and AO bone sutures with cortical screws. The same surgical approach was used for implantation of a glenohumeral joint spacer in one case. Intramedullary nails were inserted through the access path obtained from stratification of the deltoid muscle and the rotator cuff. In 15 subjects closed reduction of a fractured bone was performed under control of X-ray. Fractures were percutaneously stabilized with Kirschner wires (Table I).

No complications were observed in the course of surgery. The average hospitalization time amounted to 7 days. In hospital, patients were rehabilitated according to the same strategy corresponding with an early postoperative condition. Rehabilitation included passive and active movements in the glenohumeral joint only in patients who underwent stable osteosynthesis. The average time of follow-up amounted to 19.4 months. During further follow up, the postoperative function of the affected joint was assessed using the Constant-Murley score [7, 12]. The 
Constant-Murley score evaluated not only subjective parameters (pain) but also the objective ones (range of movement, daily living activity and muscle strength) in comparison to the undamaged side. When the difference in the Constant-Murley score was lower than 11 points, the treatment outcome was described as a very good one, and when the difference was higher than 30 points, as unsatisfactory. The Kruskal-Wallis one-way analysis of variance was used to evaluate the obtained data.

Table I. Internal fixation applied depending on the type of fracture

Tabela I. Rozktad rodzajów zastosowanych zespoleń w zależności od typu złamania

\begin{tabular}{|l|l|l|l|}
\hline & Type A & Type B & Type C* \\
\hline LCP plate $^{1}$ & $22(64.7 \%)$ & $22(75.9 \%)$ & $6(85.7 \%)$ \\
\hline AO plate & $0(0 \%)$ & $2(6.9 \%)$ & $0(0 \%)$ \\
\hline $\begin{array}{l}\text { intramedullary } \\
\text { nail }^{3}\end{array}$ & $1(2.94 \%)$ & $0(0 \%)$ & $0(0 \%)$ \\
\hline K-wires $^{4}$ & $10(29.4 \%)$ & $5(17.2 \%)$ & $0(0 \%)$ \\
\hline screws $^{5}$ & $1(2.94 \%)$ & $0(0 \%)$ & $0(0 \%)$ \\
\hline
\end{tabular}

1 - ORIF with the use of dedicated LCP plate and angular stable screws; 2 - ORIF with the use of AO plate;

3 - CRIF with the use of intramedullar y nail; 4 - CRIF with the use of K-wires; 5 - ORIF with the use of AO screws.

* Glenohumeral joint spacer was used in one Type $\mathrm{C}$ case.

\section{RESULTS}

The analysis of treatment outcomes showed that in patients surgically treated for proximal humeral fracture classified as type $\mathrm{A}$ or $\mathrm{B}$, the percentage of results described as very good and good was comparable and amounted to $55.87 \%$ and $51.71 \%$, respectively. Whereas, in the smallest group of patients with the most complex fractures classified as type $\mathrm{C}$, a good and very good result was observed only in $14.29 \%$ of the subjects (Tab. II). Nonetheless, the analysis did not show any statistically significant difference in the treatment outcome $(p>0.05)$. Multiple comparisons showed that regardless of the fracture type, patients received a similar score on the ConstantMurley scale.

Good and very good results were obtained in $54 \%$ of the cases after implantation of the LCP plate, regardless of fracture severity. A similar percentage of good and very good outcomes was also observed when bone suture was used $(50 \%)$. The statistical analysis did not reveal any significant difference in treatment results in the context of the method of osteosynthesis used, regardless of the fracture type $(\operatorname{chi} 2(3)=4.41 ; p$
$=0.211)$. None of the fixation techniques showed any advantage over other methods (tab. III).

Table II. Treatment outcomes depending on the type of fracture Tabela II. Rozkład wyników leczenia w zależności od typu złamania

\begin{tabular}{|c|c|c|c|c|}
\hline & $\begin{array}{l}\text { Type A } \\
(\mathrm{n}=34)\end{array}$ & $\begin{array}{l}\text { Type B } \\
(\mathrm{n}=29)\end{array}$ & $\begin{array}{c}\text { Type C } \\
(\mathrm{n}=7)\end{array}$ \\
\hline \multirow{4}{*}{ 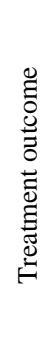 } & $\begin{array}{l}\text { poor } \\
\text { (Constant >30 pts) }\end{array}$ & $\begin{array}{c}4 \\
(11.76 \%)\end{array}$ & $\begin{array}{c}2 \\
(6.89 \%)\end{array}$ & $\begin{array}{c}1 \\
(14.29 \%)\end{array}$ \\
\hline & $\begin{array}{l}\text { satisfactory } \\
\text { (Constant 21-30 pts) }\end{array}$ & $\begin{array}{c}11 \\
(32.35 \%)\end{array}$ & $\begin{array}{c}12 \\
(41.37 \%)\end{array}$ & $\begin{array}{c}5 \\
(71.43 \%)\end{array}$ \\
\hline & $\begin{array}{l}\text { good } \\
\text { (Constant } 11-20 \mathrm{pts})\end{array}$ & $\begin{array}{c}16 \\
(47.05 \%)\end{array}$ & $\begin{array}{c}13 \\
(44.82 \%)\end{array}$ & $\begin{array}{c}1 \\
(14.29 \%)\end{array}$ \\
\hline & $\begin{array}{l}\text { very good } \\
\text { (Constant }<11 \mathrm{pts})\end{array}$ & $\begin{array}{c}3 \\
(8.82 \%)\end{array}$ & $\begin{array}{c}2 \\
(6.89 \%)\end{array}$ & $\begin{array}{c}0 \\
(0 \%)\end{array}$ \\
\hline
\end{tabular}

Table III. Treatment outcomes depending on the type of fixation

Tabela III. Rozkład wyników leczenia $w$ zależności od zastosowanego rodzaju zespolenia

\begin{tabular}{|c|c|c|c|c|}
\hline & $\begin{array}{l}\text { LCP } \\
\text { plate } \\
(\mathrm{n}=50)\end{array}$ & $\begin{array}{c}\text { Stable } \\
\text { osteosynthesis } \\
\text { (AO plate, } \\
\text { intramedullary } \\
\text { nail) } \\
(\mathrm{n}=3)\end{array}$ & $\begin{array}{c}\text { Bone suture } \\
\text { according to } \\
\text { AO } \\
\text { (K-wires, } \\
\text { screws) } \\
(\mathrm{n}=16)\end{array}$ \\
\hline \multirow{4}{*}{ 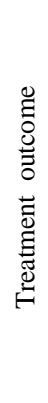 } & $\begin{array}{l}\text { poor } \\
\text { (Constant } \\
>30 \mathrm{pts} \text { ) }\end{array}$ & $\begin{array}{c}4 \\
(8 \%)\end{array}$ & $\begin{array}{c}0 \\
(0 \%)\end{array}$ & $\begin{array}{c}2 \\
(12.55 \%)\end{array}$ \\
\hline & $\begin{array}{l}\text { satisfactory } \\
\text { (Constant } \\
21-30 \text { pts) }\end{array}$ & $\begin{array}{c}19 \\
(38 \%)\end{array}$ & $\begin{array}{c}3 \\
(100 \%)\end{array}$ & $\begin{array}{c}6 \\
(37.5 \%)\end{array}$ \\
\hline & $\begin{array}{l}\text { good } \\
\text { (Constant } \\
11-20 \mathrm{pts}) \\
\end{array}$ & $\begin{array}{c}24 \\
(48 \%)\end{array}$ & $\begin{array}{c}0 \\
(0 \%)\end{array}$ & $\begin{array}{c}7 \\
(43.7 \%)\end{array}$ \\
\hline & $\begin{array}{l}\text { very good } \\
\text { (Constant } \\
<11 \text { pts) }\end{array}$ & $\begin{array}{c}3 \\
(6 \%)\end{array}$ & $\begin{array}{c}0 \\
(0 \%)\end{array}$ & $\begin{array}{c}1 \\
(6.25 \%)\end{array}$ \\
\hline
\end{tabular}

None of the short-term postoperative complications, such as: persistent edema of the limb, peripheral venostasis and axillary nerve dysfunction were observed. Besides, inflammatory complications such as: infection of surgical wound or operated area were not observed either. During postoperative observation 3 patients were diagnosed with humeral head osteonecrosis ( 2 cases with type $\mathrm{C}$ fracture and one with type B fracture). In addition, 11 patients were diagnosed with postoperative impingement syndrome ( 3 cases with type A fracture, 4 cases with type B and C each). Destabilization of osteosynthesis was discovered in 3 patients with a fracture classified as type B. Secondary dislocation of bone fragments was found in 4 cases ( 2 cases with type $B$ and $C$ fracture each). 


\section{DISCUSSION}

The above results indicate that the good outcome of surgical treatment is related neither to the fracture type nor to the fixation method used. Osteosynthesis using LCP plates and angular stable screws does not improve the treatment result in any type of the proximal humeral fracture. Hertel et al. made similar observations and did not find any advantage of bone fixation with LCP plates over the other techniques. [10, 13] In the evaluated group 3 cases of humeral head osteonecrosis were diagnosed. The complication was probably caused by the type of injury itself, especially in 2 patients diagnosed with type $\mathrm{C}$ fracture, where all 3 risk factors for humeral head osteonecrosis according to Hertel et al. were present. [11, 14] LCP plates and angular stable screws are used for standard management of the most severe cases of proximal humeral fracture, especially in patients suffering from osteoporosis. [15] However, the results are not satisfactory. Therefore, qualification to surgery should be considered individually for every patient, in the context of all the available treatment methods, especially for fractures classified as type A and B according to the AO/ASIF scale.

\section{REFERENCES}

1. Court-Brown CM, Caesar B (2006) Epidemiology of adult fractures: A review. Injury. 37:691-7.

2. Horak J, Nilsson BE (1975) Epidemiology of fractures of the upper end of the humerus. Clin Orthop. 112:250-3.

3. Lind T, Kroner K, Jensen J (1989) The epidemiology of fractures of the proximal humerus. Arch Orthop Trauma Surg. 108:285-287.

4. Barrett JA, Baron JA, Karagas MR, Beach ML (1999) Fracture risk in the U.S. Medicare population. J Clin Epidemiol. 52:243-9

5. Neer CS II (1970) Displaced proximal humeral fractures: part I - classification and evaluation. J Bone Joint Surg Am. 52 (6):1077-1089.

6. Zyto K, Ahrengart L, Sperber A, et al (1997) Treatment of displaced proximal humeral fractures in elderly patients. J Bone Joint Surg Br. 79:413-7.
7. Mills HJ, Horne G (1985) Fractures of the proximal humerus in adults. J Trauma. 25:801-805.

8. Court-Brown CM, Garg A, McQueen MM (2001) The epidemiology of proximal humeral fractures. Acta Orthop Scand. 72: 365-371

9. Roux A, Decroocq L, El Batti S, et al (2012) Epidemiology of proximal humerus fractures managed in a trauma center. Orthop Traumatol Surg Res. 98:715-719

10. Hertel R (2005) Fractures of the proximal humerus in osteoporotic bone. Osteoporos Int. 16:65-72.

11. Hanson B, Neidenbach P, de Boer P, Stengel D (2009) Functional outcomes after nonoperative management of fractures of the proximal humerus. J Shoulder Elbow Surg. 18(4):612-21.

12. Constant CR, Murley AH (1987) A clinical method of functional assessment of the shoulder. Clin Orthop Relat Res. 214:160-4.

13. Handschin AE, Cardell M, Contaldo C, et al (2008) Functional results of angular-stable plate fixation in displaced proximal humeral fractures. Injury. 39(3):30613.

14. Hertel R, Hempfing A, Stiehler M, et al (2004) Predictors of humeral head ischemia after intracapsular fracture of the proximal humerus. J Shoulder Elbow Surg. 13(4):427-33.

15. Iacobellis C, Fountzoulas K, Aldegheri R (2011) Plating of proximal fracture of the humerus: a study of 30 cases. Musculoskelet Surg. 95 Suppl 1:43-8.

Address for correspondence:

Szpital Uniwersytecki $\mathrm{Nr} 1$

Oddział Kliniczny Ortopedii

i Traumatologii Narządu Ruchu

ul. M. Skłodowskiej-Curie 9

85-094 Bydgoszcz

tel./fax (52) 5854034

sekretariat.ortopedia@cm.umk.pl

lek. med. Jakub Ohla

Marek Jedwabiński, Dariusz Mątewski -

sekretariat.ortopedia@cm.umk.pl

Received: 30.09.2015

Accepted for publication: 10.11.2015 